\title{
UJI AKTIVITAS ANTHELMINTIK BATANG KAYU KUNING (Arcangelisia flava (L.) Merr.) TERHADAP LARVA-3 Ascaridia galli
}

\author{
Melizsa \\ Sekolah Tinggi Ilmu Kesehatan Kharisma Persada \\ Tangerang Selatan, 15417, Indonesia \\ E-mail:melizsa@masda.ac.id
}

\begin{abstract}
ABSTRAK
Tanaman batang kayu kuning (Arcangelisia flava (L.) Merr.) secara tradisional digunakan untuk mengobati kecacingan. Telah dilakukan penelitian tentang uji aktivitas anthelmintik ekstrak etanol $70 \%$ batang kayu kuning (Arcangelisia flava (L.) Merr) terhadap larva-3 Ascaridia galli pada ayam ras tipe pedaging berumur 2 minggu dengan berat badan 800 - 960 gram. Penelitian menggunakan 6 kelompok hewan uji dan masing-masing kelompok terdiri dari 5 ekor ayam. Kelompok 1 sebagai kontrol normal (tanpa penginfeksian), kelompok 2 - 6 diinfeksi dengan 1000 telur infektif Acaridia galli, pada hari ke-10 setelah penginfeksian diteruskan dengan perlakuan yang berbeda pada masing-masing kelompok. Kelompok 2 sebagai kontrol negatif, kelompok 3 sebagai kontrol positif, kelompok 4, 5, 6 sebagai kelompok larutan ekstrak, dengan dosis masing-masing $26 \mathrm{mg} / 400 \mathrm{gBB}, 52 \mathrm{mg} / 400 \mathrm{gBB}, 104 \mathrm{mg} / 400 \mathrm{gBB}$. Tiga hari kemudian seluruh hewan uji dilakukan pembedahan pada bagian mukosa ususnya untuk mengetahui jumlah larva-3 Ascaridia galli yang hidup. Rata-rata jumlah larva-3 Ascaridia galli yang hidup, yaitu kelompok 1; tidak mengandung larva-3, kelompok 2; 733 ekor, kelompok 3; 52 ekor, kelompok 4; 170 ekor, kelompok 5; 91 ekor, kelompok 6; 38 ekor. Data tersebut dianalisis dengan menggunakan Anava satu arah, didapatkan nilai $\mathrm{F}$ hitung $=103,774$ lebih besar dari $\mathrm{F}$ tabel $=2,87(\alpha=0,05)$ kemudian dilanjutkan uji Tukey. Berdasarkan data analisis statistik tersebut maka dapat disimpulkan bahwa larutan ekstrak etanol $70 \%$ batang kayu kuning pada dosis $26 \mathrm{mg} / 400 \mathrm{gBB}, 52 \mathrm{mg} / 400 \mathrm{gBB}$ dan $104 \mathrm{mg} / 400 \mathrm{gBB}$ memiliki aktivitas sebagai anthelmintik. Makin tinggi dosis yang diberikan maka makin kuat daya anthelmintiknya.
\end{abstract}

Kata Kunci $\quad$ : Batang kayu kuning; Ascaridia galli; Anthelmintik; Arcangelisia flava (L.) Merr

\begin{abstract}
Yellow wood stems (Arcangelisia flava (L.) Merr.) Are traditionally used to treat worms. Research has been carried out on the anthelmintic activity of $70 \%$ ethanol extract of yellow wood stems (Arcangelisia flava (L.) Merr) against Ascaridia galli larvae in broiler breeds of 2 weeks of age with a weight of 800-960 grams. The study used 6 groups of test animals and each group consisted of 5 chickens. Group 1 as a normal control (without infection), groups 2 - 6 were infected with 1000 infective eggs of Acaridia galli, on the 10th day after infection, continued with different treatments in each group. Group 2 as a negative control, group 3 as a positive control, group 4, 5, 6 as a group of extract solutions, with a dose of $26 \mathrm{mg} / 400 \mathrm{gBB}, 52 \mathrm{mg} /$ $400 \mathrm{gBB}, 104 \mathrm{mg} / 400 \mathrm{gBB}$. Three days later all test animals were surgically removed from the intestinal mucosa to determine the number of Ascaridia galli larvae that were alive. The average number of Ascaridia galli larvae-3 that live, namely group 1; does not contain larva-3, group 2; 733 tails, group 3; 52 tails, group 4; 170 tails, group 5; 91 tails, group 6; 38 tails. The data were analyzed using one-way ANOVA, obtained F value $=103,774$ greater than $F$ table $=2,87(\alpha=0,05)$ then followed by the Tukey test. Based on the statistical analysis data, it can be concluded that the solution of $70 \%$ ethanol extract of yellow wood stems at doses of $26 \mathrm{mg} / 400 \mathrm{gBB}, 52 \mathrm{mg} / 400 \mathrm{gBB}$ and $104 \mathrm{mg} / 400 \mathrm{gBB}$ has anthelmintic activity. The higher the dose given, the stronger the anthelmintic power.
\end{abstract}

Keywords: Yellow wood stems; Ascaridia galli; Anthelmintik; Arcangelisia flava (L.) Merr 


\section{PENDAHULUAN}

Alam Indonesia yang kaya akan keanekaragaman hayati, seperti flora dan fauna telah banyak dimanfaatkan oleh masyarakat sejak zaman dahulu sebagai obat tradisional. Salah satu bahan alam yang digunakan sebagai obat tradisional adalah tanaman kayu kuning (Arcangelisia flava (L.) Merr.). Kandungan kimia yang telah diketahui adalah golongan alkaloid, flavonoid, saponin, dan tanin. Batang kayu kuning digunakan sebagai obat tradisional oleh beberapa masyarakat di Asia Tenggara, baik sebagai obat luar ataupun obat dalam, sebagai obat luar yaitu untuk mencuci luka bernanah dan penyakit gatal sedangkan yang digunakan sebagai obat dalam yaitu cairan yang keluar dari batang kayu kuning yang masih muda untuk mengobati sakit sariawan dan panas dalam, sedangkan rebusan batang kayu kuning digunakan sebagai obat penyakit kuning, gangguan pencernaan dan obat cacing (Ariyanti, 2001; Agusta, A., Jamal, Y dan Chairul, 1996).

Obat cacing atau anthelmintik adalah obat-obat yang dapat memusnahkan cacing dalam tubuh manusia dan hewan. Gejala penyakit cacing ialah terjadi gangguan lambung dan usus seperti mulas, kejang-kejang, diare serta hilangnya nafsu makan. Infeksi cacing umumnya terjadi penularan karena adanya luka di kulit yaitu pada cacing tambang dan cacing pita, sedangkan penularannya melalui tanah yaitu pada cacing gelang seperti Ascaris lumbricoides (Soedarto, 1991; Anief, M, 1996). Ascaris lumbricoides adalah cacing nematoda yang berada pada usus halus manusia yang dapat menyebabkan penyakit askariasis, maka pada penelitian ini digunakan nematoda yang menyebabkan askariasis yang sama dengan manusia yaitu Ascaridia galli yang hospesnya adalah ayam, dan penggunaan cacing Ascaridia galli ini hanya sebagai model percobaan dikarenakan tidak adanya Ascaris lumbricoides yang hospesnya selain manusia. Penelitian ini ditujukan untuk pengobatan pada manusia dengan menggunakan hewan percobaan.

Infeksi cacing Ascaridia galli terjadi melalui mulut yaitu dengan tertelannya telur yang infektif. Larva-2 hidup di dalam lumen usus halus selama 8 hari dan pada hari ke 8-17 larva menempel pada mukosa usus halus, pada hari ke-8 sesudah infeksi larva ekdisis menjadi larva-3. Larva pindah lagi ke lumen usus halus pada hari ke 18-22, menjadi cacing dewasa sekitar 5-8 minggu sesudah infeksi. Masa prepaten 
menjadi lebih lama pada ayam yang lebih tua (Soekardono, S dan Partosoedjono, S, 1992; Levine, N.D, 1990; Kusumamihardja, S, 1989).

Ayam ras memiliki sifat unggul sesuai dengan tujuan pemeliharaan dan telah mengalami perbaikan mutu genetis sehingga lebih mudah dalam proses pemeliharaan, dan digunakannya tipe pedaging dengan sifat bentuk tubuh besar dan pertumbuhan cepat. (Supritjana, E., Atmomarsono, U dan Kartasujana, R, 2005).

Pirantel pamoat sebagai zat pembanding, merupakan obat anthelmintik pilihan untuk askariasis yang mulanya digunakan untuk hewan, ternyata efektif dan kurang toksis sehingga digunakan untuk manusia. Dibandingkan

\section{METODE}

\section{Bahan}

Simplisia batang kayu kuning (Arcangelisia flava (L.) Merr.), Ayam DOC Strain Hybro PN, Pirantel pamoat, Dispersing agent PGA, Etanol 70\%, NaCl $0,9 \% \mathrm{~b} / \mathrm{v}$, Akuades.

\section{Pembuatan Ekstrak Etanol 70\%}

Serbuk simplisia batang kayu kuning sebanyak $460 \mathrm{~g}$ di maserasi dengan etanol $70 \%$ sampai seluruh sampel terendam dan cairan penyari dilebihkan setinggi lebih kurang $2 \mathrm{~cm}$ dengan obat askariasis lainnya seperti piperazin, efek samping berupa neurotoksisitas sedangkan mebendazol dan albendazole tidak boleh digunakan pada wanita hamil karena bersifat teratogen yang potensial. Pirantel pamoat bekerja dengan menimbulkan depolarisasi pada otot cacing dan meningkatkan frekuensi impuls sehingga cacing mati dalam keadaan spastis (Anonim, 1995; Tjah, T.H dan Rahardja, K, 2002).

Penggunaan batang kayu kuning (Arcangelisia flava (L.) Merr.) sebagai obat cacing sampai saat ini hanya terbatas pada penggunaan secara empiris yang diwariskan secara turun-temurun, akan tetapi hal tersebut perlu ditunjang dengan adanya penelitian ilmiah untuk membuktikan khasiat.

diatas permukaan simplisia selama 3 hari. Maserat yang diperoleh dipekatkan dalam rotary evaporator pada suhu $45^{\circ} \mathrm{C}$ sehingga diperoleh ektrak kental dan dioven pada suhu $40^{\circ} \mathrm{C}$ sampai diperoleh ekstrak kering.

\section{Penyiapan Suspensi Pirantel pamoat}

Zat pembanding Pirantel pamoat sebagai kontrol positif yang tidak larut dalam air dan metanol sehingga dibuat suspensi dengan Pulvis Gummi Arabici (PGA). Berdasarkan dosis untuk manusia 
yang dianjurkan $10 \mathrm{mg} / \mathrm{kgBB}$ dan dikonversikan ke marmut dikarenakan tidak ada data konversi ke ayam.

\section{Penyiapan Larutan Ekstrak Etanol 70\% Batang Kayu kuning}

Dosis yang digunakan secara empiris $20 \mathrm{~g}$ batang kayu kuning segar (Depkes, 1999). Penelitian ini menggunakan ekstrak kering maka dilakukan perbandingan dosis dari $1000 \mathrm{~g}$ batang kayu kuning segar menjadi $42 \mathrm{~g}$ ekstrak kering $(23,8: 1)$, karena penelitian juga menggunakan hasil data uji in vitro sebagai perbandingan dalam penentuan dosis maka dilihat apakah uji aktivitas anthelmintik secara in vitro dapat digunakan untuk menentukan dosis uji in vivo, dengan melihat berapa persen larva3 dan cacing dewasa Ascaridia galli sehingga menyebabkan paralisis selama waktu pengamatan.

\section{Penyiapan Stok Telur Infektif Ascaridia galli}

Cacing yang diperoleh dari usus ayam dicuci bersih dengan larutan $\mathrm{NaCl}$ fisiologis, kemudian ditorehkan bagian uterusnya untuk mendapatkan telurnya. Telur Ascaridia galli dapat dikumpulkan dalam waktu 24 jam, kemudian diinkubasi dengan larutan $\mathrm{NaCl}$ fisiologis pada suhu kamar selama 10 hari dalam cawan petri untuk mendapatkan telur infektif.
Penggantian $\mathrm{NaCl}$ fisiologis dilakukan setiap hari untuk menghindari kontaminasi inkubasi media telur cacing.

\section{Uji Aktivitas Anthelmintik Secara In Vitro}

Percobaan pada larva-3 dan cacing dewasa Ascaridia galli sebagai orientasi, dibagi berdasarkan konsentrasi larutan ekstrak etanol $70 \%$ batang kayu kuning yang akan diberikan, yaitu:

Kelompok 1:

Larutan ekstrak konsentrasi $1 \% \mathrm{~b} / \mathrm{v}$

Konsentrasi 2:

Larutan ekstrak konsentrasi $2 \% \mathrm{~b} / \mathrm{v}$

Konsentrasi 3:

Larutan ekstrak konsentrasi 3\% b/v

Masing-masing kelompok

dilakukan 3 kali pengulangan, 10 ekor larva-3 dan cacing dewasa Ascaridia galli masing-masing diletakkan pada cawan petri berdiameter $10 \mathrm{~cm}$ yang telah berisi $40 \mathrm{ml}$ larutan ekstrak etanol $70 \%$ batang kayu kuning.

Pengamatan jumlah larva-3 dan cacing dewasa Ascaridia galli yang paralisis dilakukan setiap jam, untuk larva-3 selama 6 jam sedangkan cacing dewasa selama 12 jam, karena larva-3 lebih rentan terhadap lingkungan luar hospesnya yaitu ayam. Paralisis yang terjadi pada larva-3 dan cacing dewasa 
Ascaridia galli dapat dikatakan jika tidak bergerak oleh rangsangan sentuhan dan bergerak sebentar kemudian langsung mati dengan temperatur air hangat.

\section{Uji Aktivitas Anthelmintik Secara In Vivo}

Jumlah ayam yang dibutuhkan tiap kelompok, dihitung berdasarkan rumus Federer yaitu (Hanafiah, 2000):

$$
\begin{array}{r}
(\mathrm{T}-1)(\mathrm{n}-1) \geq 15 \\
(6-1)(\mathrm{n}-1) \geq 15 \\
\mathrm{n} \geq 4
\end{array}
$$

Dimana:

$\mathrm{T}$ : Jumlah kelompok percobaan

$\mathrm{n}$ : Jumlah ulangan (jumlah hewan uji tiap kelompok)

Penelitian ini menggunakan 30 ekor ayam ras tipe pedaging berumur 2 minggu yang dibagi menjadi 6 kelompok dan tiap kelompok terdiri dari 5 ekor ayam. Ayam dibagi secara acak, dipelihara dengan sistem 1 kandang dan disekat untuk masing-masing ayam.

Ekstrak etanol $70 \%$ batang kayu kuning yang didapat dilakukan pengujian aktivitas anthelmintik terhadap larva-3 Ascaridia galli yang terdapat di usus ayam dan dilakukan secara in vivo. Masing-masing kelompok yang digunakan dalam percobaan ini yaitu:

Kelompok 1:
Kontrol normal untuk melihat adanya kontaminasi cacing atau tidak, ayam hanya diberi makan dan minum.

Kelompok 2:

Kontrol negatif, ayam diinfeksi dengan 1000 telur infektif, kemudian dibiarkan tanpa perlakuan pengobatan.

Kelompok 3:

Kontrol positif, ayam diinfeksi dengan 1000 telur infektif, kemudian dilanjutkan pemberian suspensi pirantel pamoat dosis $21,7 \mathrm{mg} / 400 \mathrm{gBB}$

Kelompok 4:

Ayam diinfeksi dengan 1000 telur infektif, kemudian dilanjutkan pemberian larutan ekstrak dosis I (26 mg/400 gBB)

Kelompok 5:

Ayam diinfeksi dengan 1000 telur infektif, kemudian dilanjutkan pemberian larutan ekstrak dosis II (52 mg/400 gBB). Kelompok 6:

Ayam diinfeksi dengan 1000 telur infektif, kemudian dilanjutkan pemberian larutan ekstrak dosis III (104 mg/400 $\mathrm{gBB})$.

Uji aktivitas anthelmintik secara in vivo menggunakan ayam ras DOC (Day Old Chicken) tipe pedaging yang diaklimitasi selama 2 minggu dengan pemberian Vitacik (vitamin+antibiotik). Dipergunakan anak ayam karena masa 
prepaten lebih pendek dibandingkan ayam dewasa, kemudian kelompok $2-6$ dilakukan penginfeksian dengan 1000 telur infektif cacing Ascarida galli secara oral. Hari ke-8 penginfeksian maka telurtelur infektif tersebut akan terbentuk larva-3 Ascaridia galli, kemudian dilakukan pengujian aktivitas anthelmintik ekstrak etanol $70 \%$ batang kayu kuning secara in vivo pada masingmasing kelompok larutan ekstrak pada hari ke-10 sesudah infeksi. Tiga hari kemudian seluruh ayam uji dilakukan pembedahan pada bagian mukosa ususnya untuk mengetahui jumlah larva-3 Ascaridia galli yang hidup pada kelompok percobaan.

\section{HASIL}

\section{Uji Aktivitas Anthelmintik Batang Kayu Kuning Secara In Vitro}

Tabel 1. Hasil Uji Terhadap 10 Ekor Larva-3 Ascaridia galli yang Paralisis Selama 6 Jam

\begin{tabular}{lccc}
\hline \multirow{2}{*}{ Ulangan } & \multicolumn{3}{c}{ Perlakuan } \\
\cline { 2 - 4 } & KO1 & KO2 & KO3 \\
\hline 1 & 0 & 5 & 5 \\
2 & 1 & 4 & 4 \\
3 & 1 & 4 & 5 \\
\hline Rata-rata ulangan & 0,67 & 4,33 & 4,67 \\
\hline Persentase & $6,70 \%$ & $43,30 \%$ & $46,70 \%$ \\
\hline
\end{tabular}

Tabel 2. Hasil Uji Terhadap 10 Ekor Cacing Dewasa Ascaridia galli yang Paralisis selama 12 Jam

\begin{tabular}{lccc}
\hline \multirow{2}{*}{ Ulangan } & \multicolumn{3}{c}{ Perlakuan } \\
\cline { 2 - 4 } & KO1 & KO2 & KO3 \\
\hline 1 & 1 & 5 & 6 \\
2 & 3 & 5 & 5 \\
3 & 2 & 5 & 5 \\
\hline Rata-rata ulangan & 2 & 5 & 5,33 \\
\hline Persentase & $20 \%$ & $50 \%$ & $53,30 \%$ \\
\hline
\end{tabular}

Keterangan:

KO1: Kelompok orientasi larutan ektrak, konsentrasi $1 \% \mathrm{~b} / \mathrm{v}$

KO2: Kelompok orientasi larutan ekstrak, konsentrasi $2 \% \mathrm{~b} / \mathrm{v}$

KO3: Kelompok orientasi larutan ekstrak, konsentrasi 3\% b/v 
Hasil uji aktivitas anthelmintik secara in vitro di atas menunjukkan bahwa persentase paling besar yang menyebabkan paralisis pada larva-3 dan cacing dewasa Acaridia galli yaitu pada $\mathrm{KO} 2$ dan KO3. KO2 pada larva-3 sebesar 43,30\% dan pada cacing dewasa sebesar $50 \%$. KO3 pada larva-3 sebesar $46,70 \%$ dan pada cacing dewasa sebesar 53,30\%, sedangkan KO1 pada larva-3 dan cacing dewasa hanya $6,70 \%$ dan $20 \%$. Berdasarkan hasil tersebut dapat disimpulkan bahwa ekstrak etanol $70 \%$ batang kayu kuning mempunyai aktivitas sebagai anthelmintik, maka dapat dilanjutkan pada uji aktivitas anthelmintik secara in vivo.

Hasil data jumlah larva-3 dan cacing dewasa Ascaridia galli yang paralisis secara in vitro dilakukan kenormalan menurut KolmogorovSmirnov data terdistribusi normal dan uji homogenitas Levene diketahui data terdistribusi homogen. Selanjutnya data diuji menggunakan Anava satu arah taraf uji $0,05 \quad(\alpha=0,05)$ diketahui data berbeda secara bermakna antar kelompok perlakuan. Selanjutnya dilakukan uji Tukey pada data jumlah larva-3 dan cacing dewasa Ascaridia galli yang paralisis terdapat perbedaan antara $\mathrm{KO} 1$ dengan $\mathrm{KO} 2$ dan $\mathrm{KO} 3$, sedangkan antara $\mathrm{KO} 2$ dan $\mathrm{KO} 3$ tidak terdapat perbedaan. Hal ini berarti uji aktivitas anthelmintik ekstrak etanol $70 \%$ batang kayu kuning secara in vitro dengan konsentrasi $2 \% \quad \mathrm{~b} / \mathrm{v}$ dan $3 \% \quad \mathrm{~b} / \mathrm{v}$ mempunyai kekuatan aktivitas anthelmintik yang sama.

\section{Uji Aktivitas Anthelmintik Batang Kayu Kuning Secara In Vivo}

Tabel 3. Hasil Uji Terhadap Larva-3 Ascaridia galli yang Hidup

\begin{tabular}{lrrrrrr}
\hline \multirow{2}{*}{ Perlakuan } & \multicolumn{5}{c}{ Ulangan } & $\begin{array}{r}\text { Rata- } \\
\text { rata }\end{array}$ \\
\hline \cline { 2 - 5 } K 1 & 1 & 2 & 3 & 4 & 5 & 0 \\
K 2 & 0 & 0 & 0 & 0 & 0 & 733 \\
K 3 & 671 & 654 & 890 & 576 & 873 & 52 \\
K 4 & 63 & 44 & 51 & 26 & 76 & 170 \\
K 5 & 175 & 176 & 165 & 154 & 181 & 91 \\
K 6 & 81 & 132 & 76 & 63 & 101 & 98 \\
\hline
\end{tabular}


Tabel 4. Hasil Transformasi $(\log X)$ Uji Terhadap Larva-3 Ascaridia galli yang Hidup

\begin{tabular}{lrrrrrr}
\hline \multirow{2}{*}{ Perlakuan } & \multicolumn{5}{c}{ Ulangan } & $\begin{array}{r}\text { Rata- } \\
\text { rata }\end{array}$ \\
\cline { 2 - 6 } K 2 & 1 & 2 & 3 & 4 & 5 & 2,86 \\
K 3 & 2,83 & 2,82 & 2,95 & 2,76 & 2,94 & 2,86 \\
K 4 & 1,8 & 1,64 & 1,71 & 1,41 & 1,88 & 1,69 \\
K 5 & 2,24 & 2,25 & 2,22 & 2,19 & 2,26 & 2,23 \\
K 6 & 1,91 & 2,12 & 1,88 & 1,8 & 2 & 1,94 \\
\hline
\end{tabular}

Keterangan:

Kelompok 1 (K1): Kelompok kontrol normal (tanpa penginfeksian)

Kelompok 2 (K2) : Kelompok kontrol negatif (tanpa pengobatan)

Kelompok 3 (K3) : Kelompok kontrol positif (suspensi pirantel pamoat)

Kelompok 4 (K4) : Kelompok larutan ekstrak, dosis I (26 mg/400 gBB)

Kelompok 5 (K5) : Kelompok larutan ekstrak, dosis II (52 mg/400 gBB)

Kelompok 6 (K6) : Kelompok larutan ekstrak, dosis III (104 mg/400 gBB)

Pengamatan uji in vivo di atas menunjukkan rata-rata jumlah larva-3 Ascaridia galli yang hidup, yaitu: K1 tidak terdapat larva-3 ataupun bentuk lain dari cacing Ascaridia galli dan jenis cacing lainnya, karena pada kelompok ini tidak dilakukan penginfeksian telur infektif Ascaridia galli. Berdasarkan hasil tersebut terlihat bahwa pemberian larutan ekstrak pada dosis 104 mg/400 gBB mempunyai aktivitas anthelmintik yang lebih mendekati kontrol normal.

Berdasarkan uji kenormalan Kolmogorov- smirnov data tidak terdistribusi normal dan pada uji Levene data tidak terdistribusi homogen pada kelompok percobaan, maka tidak dapat langsung dilakukan uji Anava tetapi ditransformasi terlebih dahulu dengan log $\mathrm{x}$, setelah ditransformasi baru dapat dilakukan uji Anava satu arah untuk melihat ada atau tidaknya perbedaan antar perlakuan. Penelitian ini juga diamati berat badan ayam sebelum dan sesudah dilakukan pengobatan untuk melihat apakah infeksi larva-3 Ascaridia galli dan sesudah dilakukan pengobatan dengan menggunakan larutan ekstrak etanol $70 \%$ batang kayu kuning berpengaruh terhadap berat badan ayam. 
Hasil pengamatan dapat dilihat pada tabel berikut:

Tabel 5. Berat Badan Ayam (gram) Sebelum Pengobatan, Berumur 24 Hari

\begin{tabular}{lrrrrrr}
\hline \multirow{2}{*}{ Perlakuan } & \multicolumn{5}{c}{ Ulangan } & $\begin{array}{r}\text { Rata-rata } \\
\text { nyyrat Badan }\end{array}$ \\
\cline { 2 - 5 } K1 & 1 & 2 & 3 & 4 & 5 & Berat Bar \\
K2 & 1140 & 1040 & 1140 & 1000 & 1000 & 896 \\
K3 & 900 & 960 & 920 & 860 & 840 & 880 \\
K4 & 800 & 900 & 880 & 930 & 890 & 910 \\
K5 & 900 & 880 & 960 & 940 & 870 & 894 \\
K6 & 890 & 870 & 950 & 920 & 840 & 898 \\
\hline
\end{tabular}

Tabel 6. Berat Badan Ayam (gram) Sesudah Pengobatan, Berumur 27 Hari

\begin{tabular}{lrrrrrr}
\hline \multirow{2}{*}{ Perlakuan } & \multicolumn{5}{c}{ Ulangan } & $\begin{array}{r}\text { Rata-rata } \\
\text { Berat Badan }\end{array}$ \\
\cline { 2 - 5 } K1 & 1 & 2 & 3 & 4 & 5 & 1120 \\
K2 & 1160 & 1060 & 1200 & 1060 & 1120 & 784 \\
K3 & 760 & 860 & 820 & 740 & 740 & 1060 \\
K4 & 1020 & 1060 & 1020 & 1160 & 1040 & 888 \\
K5 & 880 & 840 & 920 & 900 & 900 & 984 \\
K6 & 960 & 920 & 1020 & 1020 & 1000 & 1100 \\
\hline
\end{tabular}

Hasil pengamatan di atas menunjukkan bahwa rata-rata berat badan ayam sebelum pengobatan kelompok kontrol normal (tanpa penginfeksian) yaitu $1064 \mathrm{~g}$, sedangkan kelompok perlakuan penginfeksian adalah kontrol negatif (K2), kontrol positif (K3), dosis I
(K4), dan dosis II (K5), dan dosis III (K6) rata-rata berat badan ayam berturut-turut yaitu 896 g, 880 g, 910 g, 894 g, 898 g. Angka ini menunjukkan bahwa ayam yang tidak diinfeksi rata-rata berat badannya lebih besar dari ayam yang diinfeksi. 


\section{DISKUSI}

Pada uji aktivitas anthelmintik secara in vitro, larutan ekstrak etanol $70 \%$ batang kayu kuning di dalam cawan petri menggunakan $\mathrm{NaCl}$ fisiologis sebagai pelarut dan seluruh permukaan tubuh tertutup oleh larutan ekstrak karena dikondisikan larva-3 dan cacing dewasa Ascaridia galli berada pada cairan tubuh hospes sehingga tekanan osmose pada larutan ekstrak sama dengan cairan tubuh pada hospesnya, karena jika tidak dikondisikan sama dengan cairan tubuh maka larva-3 dan cacing dewasa Ascaridia galli dapat mengalami paralisis dan akhirnya mati karena mungkin terjadi nekrosis, rangsangan pada selaput otak dan hemolisa sehingga nantinya pengamatan tidak dapat diambil sebagai hasil uji aktivitas anthelmintik secara in vitro dengan melihat berapa persen yang menyebabkan paralisis.

Penelitian ini simplisia menggunakan penyari etanol $70 \%$ untuk mendapatkan sediaan yang tahan lebih lama karena bakteri dan kapang tidak dapat tumbuh di dalamnya dan penyari etanol $70 \%$ dapat melarutkan zat aktif yang lebih baik dan zat pengganggu yang larut hanya terbatas sehingga dapat menghasilkan sediaan yang lebih baik dibandingkan dengan penyari air karena ekstrak dapat ditumbuhi kapang dan bakteri, dan penyari air tidak hanya melarutkan zat aktif tetapi juga melarutkan zat pengganggu dan enzim yang dapat menurunkan kualitas sediaan ekstrak. Pada penelitian ini yang digunakan adalah ekstrak kering maka dikonversi dari simplisia segar ke ekstrak kering $(23,8: 1)$, jadi $20 \mathrm{~g} \mathrm{x} \mathrm{1/23,8=0,84}$ $\mathrm{g}(840 \mathrm{mg})$.

Penelitian ini menggunakan ayam sebagai hewan uji maka dosis yang digunakan untuk manusia dikonversi ke ayam, akan tetapi tidak ada data konversi ke unggas maka dosis dikonversikan dengan berat badan ayam yang mendekati ke data konversi yang ada yaitu marmut 0,031/400 gBB, sehingga $0,84 \mathrm{~g} \times 0,031=$ $0,026 \mathrm{~g}(26 \mathrm{mg})$ dan untuk interval dosis selanjutnya $2 \times \mathrm{n}$, sehingga dosis yang digunakan untuk uji in vivo adalah 26 $\mathrm{mg} / 400 \mathrm{gBB}, 52 \mathrm{mg} / 400 \mathrm{gBB}, 104$ $\mathrm{mg} / 400 \mathrm{gBB}$.

Uji anthelmintik secara in vivo digunakan 30 ekor ayam ras karena bersifat unggul sesuai dengan tujuan pemeliharaan karena telah mengalami perbaikan mutu genetis sehingga lebih mudah dalam proses pemeliharaan, dan 
digunakannya tipe pedaging dengan sifat bentuk tubuh besar dan pertumbuhan cepat, karena pada penelitian ini yang diamati tidak hanya pada jumlah larva-3 Ascaridia galli yang hidup setelah pengobatan tetapi juga diamati pengaruhnya terhadap berat badan ayam. Ayam DOC yang diperoleh dari PT.Peternakan Ayam Manggis, Jakarta diaklimitasi selama 2 minggu dengan pemberian Vitacik untuk kekebalan tubuh ayam, sehingga mencegah infeksi lain yang tidak diinginkan karena setelah diinfeksikan diharapkan hanya terjadi infeksi tunggal untuk memperoleh hasil yang lebih akurat pada jenis cacing Ascaridia galli dan tidak dipengaruhi oleh jenis cacing lain yang bukan sasaran penelitian. Dari 30 ekor ayam tersebut dibagi menjadi 6 kelompok dan masingmasing kelompok terdiri dari 5 ekor ayam sebagai ulangan perlakuan. K1 merupakan kontrol normal untuk melihat adanya kontaminasi cacing atau tidak pada hewan uji dan kelompok $2-6$ dilakukan penginfeksian dengan 1000 telur infektif cacing Ascaridia galli secara oral dan diteruskan dengan perlakuan yang berbeda pada masing-masing kelompok.
Hari ke-10 telur infektif yang telah diinfeksikan tersebut telah terbentuk menjadi larva-3 Ascaridia galli, digunakan larva-3 pada uji in vivo ini karena untuk mengetahui aktivitas ekstrak etanol $70 \%$ batang kayu kuning terhadap bentuk imatur dari cacing Ascaridia galli dengan siklus hidup yang lebih cepat waktunya dibandingkan dengan bentuk matur cacing Ascaridia galli yang masa prepatennya jauh lebih lama. K2 merupakan kontrol negatif tanpa dilakukan pengobatan. K3 merupakan kontrol positif dengan menggunakan suspensi pirantel pamoat sebagai pembanding, menurut literatur dosis tunggal pirantel pamoat $10 \mathrm{mg} / \mathrm{kgBB}$ untuk manusia, karena pada penelitian ini menggunakan ayam sebagai hewan uji maka dikonversikan menjadi 21,7 mg/400 gBB. K4, K5 dan K6 merupakan kelompok larutan ekstrak etanol 70\% batang kayu kuning dengan masingmasing dosis $26 \mathrm{mg} / 400 \mathrm{gBB}, 52 \mathrm{mg} / 400$ gBB, 104 mg/400 gBB. Tiga hari setelah pengobatan seluruh kelompok hewan uji dilakukan pembedahan pada bagian mukosa ususnya, larva-3 Ascaridia galli diambil dari usus halus dengan cara memijit perlahan-lahan organ tersebut dengan pinset, dan disaring ke dalam 
gelas piala yang berisi larutan $\mathrm{NaCl} 0,9 \%$ b/v, maka akan akan terlihat adanya endapan pada larutan yang menunjukkan adanya larva-3 Ascaridia galli. Endapan tersebut dipipet dan dipindahkan ke dalam cawan petri untuk dilihat dengan menggunakan mikroskop, agar dapat dihitung jumlah larva-3 Ascaridia galli yang hidup. Seluruh pengamatan larva-3 Ascaridia galli pada larutan $\mathrm{NaCl} 0,9 \%$ b/v dalam keadaan hidup semua tidak ada yang paralisis/mati, itu menunjukkan bahwa larva-3 yang paralisis/mati ketika berada di dalam tubuh hospes akan langsung dieksresikan, karena tubuh larva-3 terjadi depolarisasi otot sehingga terjadi spastis yang menyebabkan larva-3 tidak dapat bertahan untuk menempel mukosa usus.

Berdasarkan hasil perhitungan uji Anava satu arah pada hasil transformasi $(\log \mathrm{x})$ uji aktivitas anthelmnintik batang kayu kuning secara in vivo taraf uji 0,05 $(\alpha=0,05)$ diketahui data berbeda secara bermakna antar kelompok perlakuan, selanjutnya data tersebut dilakukan uji Tukey. Berdasarkan hasil uji Tukey pada data terdapat perbedaan antara kontrol negatif dengan kontrol positif (K3), larutan ekstrak etanol 70\% batang kayu kuning dosis $26 \mathrm{mg} / 400 \mathrm{gBB}(\mathrm{K} 4), 52$ mg/400 gBB (K5), dan 104 mg/400 gBB (K6). Perbedaan juga terlihat antara K4 dengan kelompok lainnya dan antara K5 dengan kelompok lainnya. Tidak terdapat perbedaan antara kontrol positif dengan larutan ekstrak etanol $70 \%$ batang kayu kuning dosis 104 mg/400 gBB. Hal ini berarti, kontrol positif mempunyai aktivitas anthelmintik yang sama dengan K6. Berdasarkan kelima data analisis statistik (K2 - K6) maka bahwa larutan ekstrak etanol $70 \%$ batang kayu kuning pada dosis $26 \mathrm{mg} / 400 \mathrm{gBB}, 52 \mathrm{mg} / 400$ $\mathrm{gBB}$, dan dosis $104 \mathrm{mg} / 400 \mathrm{gBB}$ mempunyai aktivitas sebagai anthelmintik.

Hasil pengamatan rata-rata berat badan ayam sesudah pengobatan pada $\mathrm{K} 1$ yaitu 1120 g, K2 yaitu 784 g, K3 yaitu $1060 \mathrm{~g}$, kelompok larutan ekstrak etanol $70 \%$ batang kayu kuning dosis 26 mg/400 gBB (K4), 52 mg/400 gBB (K5), dan 104 $\mathrm{mg} / 400 \mathrm{gBB}$ (K6) rata-rata berat badan ayam berturut-turut yaitu 888 g, 984 g, 1100 g. Angka ini menunjukkan bahwa dengan dilakukan pengobatan terhadap ayam uji akan mempengaruhi peningkatan berat badan ayam tersebut.

Hasil data berat badan ayam sebelum dan sesudah pengobatan dilakukan uji kenormalan menurut 
Kolmogorov-Smirnov data terdistribusi normal dan uji homogenitas Levene diketahui data terdistribusi homogen. Selanjutnya data diuji menggunakan Anava satu arah pada taraf uji $0,05(\alpha=$ 0,05) diketahui data berbeda secara bermakna antar kelompok perlakuan, selanjutnya data tersebut dilakukan uji Tukey. Berdasarkan hasil uji Tukey pada berat badan ayam sebelum pengobatan tidak terdapat perbedaan antara kontrol normal (K1) dengan kontrol negatif (K2), kontrol positif (K3), K4, K5, dan K6. Hal ini berarti bahwa dengan dilakukan penginfeksian cacing Ascaridia galli terhadap ayam uji berpengaruh terhadap penurunan berat badan ayam tersebut, karena ayam yang diinfeksi sari-sari makanan yang terdapat di dalam tubuh diambil oleh Ascaridia galli, sehingga asupan nutrisi untuk pertumbuhan ayam berkurang.

Hasil uji Tukey pada berat badan ayam sesudah pengobatan terdapat perbedaan antara kontrol negatif dengan kontrol normal, kontrol positif, larutan ekstrak etanol $70 \%$ batang kayu kuning dosis II (52 mg/400 $\mathrm{gBB})$ dan dosis III (104 mg/400 gBB), tetapi pada dosis I (26 $\mathrm{mg} / 400 \mathrm{gBB}$ ) tidak terlihat adanya perbedaan. Hal ini berarti besarnya jumlah larva-3 Ascaridia galli yang terdapat dalam tubuh ayam pada $\mathrm{K} 4$ (dosis I) mempengaruhi penurunan berat badan ayam yang sama dengan besarnya jumlah larva-3 Ascaridia galli yang terdapat pada kontrol negatif. Perbedaan juga terlihat antara kontrol normal dengan kontrol negatif, dosis I dan dosis II, tetapi pada kontrol positif dan dosis III tidak terlihat adanya perbedaan. Hal ini berarti besarnya jumlah larva-3 Ascaridia galli yang terdapat dalam tubuh ayam pada larutan ekstrak etanol $70 \%$ batang kayu kuning dosis III (104 mg/400 gBB) dan kelompok kontrol positif tidak mempengaruhi berat badan ayam karena tidak adanya perbedaan berat badan ayam dengan kelompok kontrol normal.

\section{SIMPULAN}

Pemberian ekstrak etanol $70 \%$ batang kayu kuning dengan dosis 26 mg/400 gBB, 52 mg/400 gBB, 104 mg /400 gBB pada ayam ras tipe pedaging mempunyai aktivitas sebagai obat cacing/ anthelmintik. Semakin tinggi dosis yang diberikan maka semakin kuat daya anthelmintiknya. 


\section{DAFTAR PUSTAKA}

Ariyanti, E.E. 2001. Mengenal Sirawan (Arcangelisia flava (L.) Merr.) Tumbuhan Langka yang Berkhasiat Obat. Dalam: Warta Kebun Raya Majalah Semipopuler/Populer. Vol 3(1). Pusat Konservasi Tumbuhan Kebun Raya Bogor. Bogor: Lembaga Ilmu Pengetahuan Indonesia.

Anief, M. 1996. Penggolongan Obat Berdasarkan Khasiat dan Penggunaan. Yogyakarta: Gajah Mada University Press.

Agusta, A., Jamal, Y. Dan Chairul. 1996. Komponen Kimia Fraksi Non Polar Arcangelisia flava (Menispermaceae). Jakarta: Majalah Farmasi Indonesia.

Anonim. 1995. Farmakologi dan Terapi (Edisi IV). Jakarta: Bagian Farmakologi Kedokteran Universitas Indonesia.

Departemen Kesehatan Badan Penelitian dan Pengembangan Kesehatan. 1999. Inventaris Tanaman Obat Indonesia (V). Jakarta: Depkes.
Hanafiah, Kemas, A. 2000. Rancangan Percobaan Teori dan Aplikasi (Edisi Revisi). Jakarta: PT Raja Grafindo Persada.

Kusumamihardja, S. 1989. Parasit dan Parasitosis Pada Hewan Ternak dan Hewan Piaraan di Indonesia. Bogor: Pusat Antar Universitas Bioteknologi IPB.

Levine, N.D. 1990. Buku Pelajaran Parasitologi Veteriner. Yogyakarta: Gadjah Mada University Press.

Soedarto. $1991 . \quad$ Helmintologi Kedokteran. Jakarta: Buku Kedokteran EGC.

Soekardono, S dan Partosoedjono, S. 1992. Parasit-parasit Ayam. Jakarta: Gramedia.

Supritjana, E., Atmomarsono, U., dan Kartasujana, R. 2005. Ilmu Dasar Ternak Unggas. Jakarta: Penebar Swadaya.

Tjay, T.H dan Rahardja, K. 2002. Obatobat Penting Khasiat, Penggunaan, dan Efek-efek Sampingnya (Edisi V). Jakarta: PT Gramedia. 